\title{
Tutkimustiedon saatavuus on jatkuvan koulutuksen peruspilari
}

\section{Tutkimusraporttien ja aikuiskasvatusta käsittelevien teosten läpikäyminen oli työryhmän yksittäisille jäsenille erinomaisen antoisa tehtävä. Lähes puolen vuoden työrupeaman jälkeen moni meistä olisi ollut valmis jatkamaan arviointia säännöllisesti myöhemminkin! Tutkimustiedon entistä laajempi leviäminen on eräs tärkeimmistä suomalaisen aikuiskasvatuksen laatutason varmistajista.}

Kolme kunnollisen painoasun saanutta julkaisua, nimittäin Ikääntyminen ja työ, Oppiminen ja koulutus sekä Alioikeudet uuden työtavan kynnyksellä, nostattivat keskustelun siitä, miten arviointityössä olisi tullut kohdella tiedekuntien sarjoissa ilmestyneitä, niukalla rahalla tehtyjä tutkimusraportteja ja toisaalta kaupallisen kustantajan kautta ilmestyneitä, suurempaa lukijakuntaa tavoittelevia teoksia. Teokset päätettiin eräässä vaiheessa jakaa toisaalta oppikirjojen ja perusteosten ja toisaalta tutkimusraporttien sarjoihin. Tämä jaottelu ei ollut ongelmaton, sillä jokainen teos näytti viime kädessä sijoittuvan omaan sarjaansa.

Varsinaiset tieteelliset tutkimusraportit julkaistaan nykyisin pääasiallisesti muutaman sadan kappaleen painoksina yliopistollisissa julkaisusarjoissa. Painosmäärät ovat lamavuosien aikana entisestään pienentyneet. Moni julkaisu on loppuunmyyty lyhyessä ajassa ilmestymisensä jälkeen.

Tällaisten raporttien laajempaa käyttöarvoa työryhmä piti heikkona. julkaisun painosmäärän on oltava riittävän suuri, jotta kohderyhmän jäsenillä ("aikuiskouluttajat") olisi mahdollisuus hankkia se käyttöönsä edes tieteellisistä kirjastoista kohtuullisella tilausajalla.

Joissakin yliopistoissa on selvästi tiedostettu pienten painosmäärien ongelma ja tutkimusraportteja on pyritty julkaisemaan yhteistyössä jonkun muun organisaation kanssa. Hyvä esimerkki tästä on Turun yliopiston koulutussosiologian tutkimusyksikkö ja sen yhteistyö tilastokeskuksen kanssa. Raporttien markkinointi on saatu näin riittävän laajalle pohjalle ja tutkimukset uusien lukijajoukkojen tietoisuuteen. Vastaavaa yhteistyötä kannattaisi myös perinteisten tiedekuntien ryhtyä harjoittamaan erityisesti sellaisten tutkimuslaitosten kanssa, joilla on vakiintuneet markkinointikanavat. Sillä miksi oikeastaan tiedeyhteisöjen pitäisi hallita markkinoinnin ja kustannuslaskennan monimutkaiset pelisäännöt?

Entä olisiko mahdollista joissakin tilanteissa saada aikaan yliopistojen keskinäistä yhteistyötä julkaisutoiminnassa? Mehän emme kilpaile vain keskenämme tutkimuksen tasokkuudesta ja määristä, vaan kärkitutkimuksilla ja vahvuusalueilla kilpaillaan tulevaisuudessa yhä useammin kansainvälisesti mm. EU:n projekteista. Haasteemme on siinä, miten kykenemme osoittamaan tasokkaan humanistisen tutkimuksen tarpeellisuuden suhteessa tällä foorumilla paljon suurempaa arvostusta nauttivaan teknologiseen tutkimukseen. Tämän vuoksi tarvitsemme nykyistä huomattavasti enemmän kansainvälisiä tutkimushankkeita kasvatustieteissä.

\section{Kielikysymys on tärkeä}

Työryhmä arvioi niin suomen- kuin englanninkieliset julkaisut käyttämällä samoja arviointikriteereitä. Ruotsiksi kirjoitettuja aikuiskasvatuksen raportteja ei tarjottu arvioitavaksi lainkaan, mitä voisi oikeastaan 
ihmetellä, sillä skandinaviset yhteistyöverkostot toki ovat olleet aikuiskasvatuksessa jo vuosikymmenet olemassa.

Kansainväliset, yhteiset tutkimusprojektit ovat lisääntymässä ja niiden tarve on aikuis- ja ammattikasvatuksen alueilla ilmeinen. Suomalainen tutkimus on myös niin laadukasta, että sitä on perusteltua viedä kansainvälisen lukijakunnan tietoisuuteen. Itse olisin nostamassa väitöskirjojen vaatimustasoa niin, että ne pääsääntöisesti julkaistaisiin vieraskielisinä. Tästä tosin seuraa uusia ongelmia, mutta ne tuskin ovat ylipääsemättömän hankalia tai kalliita.

Parhaana ratkaisuna saattaisi olla kaksitasoinen raportointi: tutkijoille ja muulle käyttäjäkunnalle tarkoitetut osuudet tuotettaisiin omina kokonaisuuksinaan: varsinainen työ esimerkiksi englanniksi ja tiivistelmä suomeksi. Vieraskielinen tutkimusraportti tavoittaa kuitenkin kotimaassa väistämässä vähemmän lukijoita kuin suomeksi kirjoitetut julkaisut. Käyttötietoa haetaan nimittäin useimmiten omalla äidinkielellä siitä arkisesta syystä, että useimmat meistä lukevat sitä nopeammin. ja käyttötietoa tarvitaan nopeasti.

Raportti ei myöskään voi olla abtraktiotasoltaan sellainen, että sen sulatteluun tarvitaan useiden kuukausien mietiskely. Monet väitöskirjat kuitenkin ovat teoreettisia ja niiden on oltava teoreettisia. Perustutkimuksen ja soveltavan tutkimuksen ero on olennainen myös aikuiskasvatustieteessä. Silti myös teoreettisella perustutkimuksella on runsaasti annettavaa käytäntöön. Tutkija itse taitaisi olla paras henkilö miettimään tätä sidosta. Vaan kykeneekö hän siihen? Mitä on tutkijakoulutuksessa pidetty tärkeänä?

Jokaisesta tutkimuksesta olisi joka tapauksessa oltava saatavilla sekä vieraskielinen että suomenkielinen tiivistelmä. Eikä ainoastaan englanninkielisinä, vaan yhä useammin ranskaksi ja saksaksi. Tietoverkkojen käyttöönottoa tutkimustiivistelmien levittämisessä tulisi myös jouduttaa.

\section{Tieteellisen kirjoittamisen tasoja on monia}

Oma erilliskysymyksensä kielikysymykseen liittyen on se, miten tutkijayhteisöt hallitsevat tai näkevät mielekkääksi tutkimustulostensa esittelemisen varsinaisia tiedepiirejä laajemmille käyttäjäryhmille. Yliopistojen kesken on huomattavia eroja siinä, miten tieteellisistä tutkimustuloksista tiedotetaan ja miten omia tuoreita tutkimustuloksia onnistutaan saamaan uutiskynnyksen yli. Tieteellisen tutkimustiedon levittämiseen suurelle yleisölle suhtaudutaan vielä yllättävänkin nihkeästi miettimättä lainkaan, että resurssointi lepää monella aikuiskasvatuksen lohkolla paljolti sen mielikuvan ja vakuuttavuuden varassa, joka tästä tieteenalasta on kyetty julkisuudessa luomaan. Se mitä yliopistoissa tehdään, heijastuu yhteiskunnassa koko aikuiskoulutuksen nauttimaan arvostukseen.

Tieteellisen tiedon levittäminen on kiistämättä erityisosaamista vaativa alue. Se vaatii toisenlaisia taitoja ja kirjoittamisen keinoja kuin tutkimusraportin tuottaminen. Aikuiskasvatuksen alueen pohdintojen ja tutkimustuloksien pitämistä vain harvojen saatavilla ei voida pitää perusteltuna. Tämän vuoksi tulisi koulutusohjelmissa perusopinnoista lähtien harjoitella tieteellisen tekstin kirjoittamista monenlaisille lukijakunnille ja monilla kielillä. En usko, että tieteellinen tutkimustulos olisi yhtään sen vähemmän "tieteellinen", jos se julkistetaan yleiskielisesti lyhennettynä ydinkohtiin. Lukevan väestön koulutustaso on noussut sitten niiden päivien, jolloin tieteellinen tieto oli lähes mystifioitua.

Eikä aikuiskasvatus ole ennenkään vaalinut salakabinettien tiedeideaalia, jonka mukaan tieto on vallankäytön eräs muoto ja liika viisaus yhteiskunnassa vaarallista. Ei julkisesti ainakaan. Mahdollisista piilomekanismeista en rohkene sanoa mitään, sillä tämä koko kirjoitukseni perustuu vaikutelmille, ei tutkimukseen.

\section{Yleisiä huomioita aikuiskasvatuksen tutkimuksista}

Hajakommentteina aikuiskasvatuksen tutkimuksesta voisin todeta seuraavaa: 
- vapaan sivistystyön asema on vähäinen aikuiskasvatuksen tutkimuskentässä. Miksi? Puoli miljoonaa suomalaista osallistuu vuosittain kansalaisopistojen toimintaan, kansanopistot hakevat uusia toimintamahdollisuuksia, opintokerho- ja järjestötoimintaa on vielä olemassa! Gradutason tutkimuksia tältä alueelta tehdään ja siksi voisi oikeastaan osoittaa toiveensa jatkotutkimusten apurahojen myöntäjille. Kannattaisiko niukkoja rahoja suunnata vapaan kansansivistyksen alueen tutkimuksiin muutoinkin kuin oppilaitoshistoriikkien muodossa?

- tutkijat ovat kiitettäväsi tarttuneet ajankohtaisiin, yhteiskunnallisesti tärkeisiin aiheisiin (mm. työttömien koulutukseen, jatkuvaan koulutukseen, itseohjautuvuuteen, työpaikkakoulutukseen, vanhenevan ihmisen koulutukseen).Tilanne on siis kasvatustieteessä parempi kuin mistä Erik Allardt on tänä syksynä arvostellut sosiologista tutkimusta.

- mutta missä ovat tasa-arvo- ja naistutkimukset? Päivi Naumasen "Tiedon, taidon ja vallan tiellä." on erinomainen makrotarkastelu, mutta tilaa tämän alueen intensiivisille tutkimuksille olisi enemmänkin. Vaikuttavatko ohjaajien mielekkäinä pitämät asiat sittenkin aihevalinnoissa? Vai onko tämä huomio sidoksissa vapaan sivistystyön vähäiseen osuuteen tutkimusten joukossa? Kuten Naumanen toteaa miesten ja naisten kouluttautumisesta:

"Aikuiskoulutukseen osallistuneiden miesten ja naisten opinnot erosivat siten, että naiset opiskelivat miehiä selvästi useammin harrastustarkoituksessa ja itseänsä kehittääkseen, kun taas miehet opiskelivat naisia jonkin verran enemmän ammatillisessa tarkoituksessa ja työnantajan velvoittamina. Naiset opiskelivat omasta aloitteestaan, omalla ajallaan (vapaa-aikanaan) ja omalla kustannuksellaan, kun taas miehet olivat koulutuksessa työajalla tai työnantaja muutoin kustansi heidän opiskelunsa. Naiset kustansivat ammatillisetkin opintonsa itse ja opiskelivat vapaa-ajallaan työtään varten miehiä useammin."

- tutkimuksia rasittaa "lokeroituminen". Oman yliopiston tai yhteisön näkemykset ovat korostuneesti esillä, mutta muihin ei liiemmälti esitetä viittauksia. Tuskin ketään kuitenkaan sanottavammin hyödyttää esimerkiksi jonkun tieteentekijän tuotannon mitätöinti yrittämällä vaieta siitä totaalisesti. Päinvastoin. Aikuiskasvattajina ja -kouluttajina toimiville henkilöille olisivat erinomaisen käyttökelpoisia työvälineitä erilaisten, eroavien teoreettisten näkökohtien vertailut ja vaikkapa vastakkaisten argumenttien tarkastelu yhdessä opiskelijoiden kanssa. Tämä olisi olennaisesti helpompaa, jos tieteellistä väittelyä olisi jossain raportoituna. Siis missä on kotimainen tieteellinen väittely?

- aikuiskasvatuksen alueen tutkimuksen suomalainen vahvuus on metodisessa monipuolisuudessa. Lähes joka lähtöön on vankkaa osaamista olemassa: kvantitatiivista, kvalitatiivista, tilastollista, historiallista jne.. Silti raporttien metodologinen suuntaus näyttää olevan yliopistokohtaista. Sosiaalistuuko tieteentekijä yhteisöönsä liiankin voimakkaasti? Hyväksytäänkö valtavirrasta poikkeava tieteentekijä tiedeyhteisössä? Näyttäisi siltä, että tässä "sietokyvyssä" tai "oikean (?!) tutkimusmallin opettamisessa" on selviä eroja eri yliopistojen kesken.

- muodolliset opinnäytetyön raamit tuntuvat monessa raportissa jäykistävän esitystapaa. Kronologinen esitys saattaisi välittää aidomman ja luotettavamman kuvan tutkitusta ilmiöstä kuin perinteinen töiden jäsentely teoreettiseen ja empiiriseen tarkasteluun.

\section{Käyttötutkimuksia monenlaiseen käyttöön}

Mielenkiintoisinta luettavaa käytännön kannalta syntyy, jos:

1) tutkimusraportti on tehty todellisessa aikuiskasvatuksen ja -koulutuksen ympäristössä ja sieltä nousseiden tutkimustehtävien ohjaamana, tai 
2) empiiristen ja teoreettisten tutkimusten perusteella on laadittu syvästi omakohtainen pohdiskeleva, käytäntöön kurkotteleva synteesi, tai

3) tutkimusraportti on monien eri tieteenalojen edustajien ja ammattitaitoisen toimittajan/ kustantajan yhteistyön tulos.

Lopuksi on vielä palattava arvioimityön peruslähtökohtaan ja siihen, kuka itse asiassa on aikuiskasvattaja. On aivan varma, että ammatillisen aikuiskoulutuskeskuksen työllisyyskurssin vetäjä miettii opetustilanteitaan toisin kuin kesäyliopiston opettaja, tai veneentervauskurssin pitäjä Lapissa. Tai yritysmaailman armottomaan kilpailuun syöksyvä kouluttajakonsultti.

Silti näen kovasti yhteistä kaikille kouluttajille. Se yhteinen osuus on nimeltään kasvattajan etiikka. Halu vuorovaikutukseen ihmisten kanssa, halu etsiä kasvun kipinää. Halu elää ajassa ja inhimillisyyden, humanismin hengessä. Aikuiskasvattajan yhteiskunnallista vastuuta pelkäämättä.

Kosti Huuhka on sanonut saman asian kolmisenkymmentä vuotta sitten:

"Sosiaalinen turvallisuus voidaan rakentaa vain riittäville aineellisille perusteille. Vaikka sosiaalisella tasauksella voidaan niukatkin varat ja palvelut jakaa oikeudenmukaisemmin, todellinen hyvinvointi edellyttää niiden lisäämistä. On toisin sanoen pystyttävä tuottamaan enemmän niin hyödykkeitä kuin palveluksiakin ja tuottamaan niitä korkeatasoisempina. jotta tähän kyettäisiin, tarvitaan runsaasti tietoa: monitahoista ja korkeatasoista tietoa. Tietoa tarvitsevat kaikki eivätkä vain muutamat.

Sosiaalinen kehitys ei ole kuitenkaan vain aineellisten edellytysten varassa. Tämä kehitys on tapahtuma, joka toisaalta koskee jokaista, mutta jossa myös jokainen voi olla ja jokaisen tulisi olla siihen vaikuttamassa, jotta se todella edistäisi hyvinvointia ja turvallisuutta. Tämä mukanaolo, vaikuttaminen taas edellyttää tietoa; tietämättömän on perin huono vaikuttaa tai hänen vaikutustaan ohjaavat muut mielensä mukaan. Olemme valmiit kyllä ottamaan vastaan sosiaalisen kehityksen annin, mutta unohdamme helposti, että olemme osaltamme vastuussa siitä." (Juhlapuhe "Kasvatuksen merkitys sosiaalisen turvallisuuden lisääjänä" Harjulan kansalaisopiston 30- vuotisjuhlassa vuonna 1971. Yhdysside nro 9-10/ -71 s. 22-23)

\section{Keskustelu jatkuu}

Lehti jatkoa keskustelua aikuiskasvatustutkimuksen sovellettavuudesta julkaisemalla seuraavassa numerossa $\mathrm{mm}$. Juha Suorannan artikkelin 'Aikuiskasvatustutkimuksen sovellettavuudesta ja käytännön ongelmisto'. Luvassa on myös lisää aikuiskasvatustutkimusten arviointia julkaistuina normaaleina kirja-arvioina ja -esittelyinä. 